\title{
Axiology on the Integration of Knowledge, Islam and Science
}

\author{
Mas'ud Zein \\ Department of Islamic Education, Faculty of Education and Teacher Training, UIN Suska Riau, Indonesia \\ m.zen_zen@yahoo.com \\ DOI: http://dx.doi.org/10.15548/jt.v21i2.93
}

\begin{abstract}
The integration of Islamic and science was done through integration-interconnected, referring to ontological, epistemological dan axiological perspectives. This paper will focus on the integration of Islam and science from axiological perspective. In the view of axiology, science is seen as neutral and value-free; the value of science is given by its users. This condition motivates Muslim scholars to reintegrate science and religion. The first attempt made is my giving ideas on the Islamization of science. The attempt to Islamize the science in the Islamic world is dilemmatic, whether to wrap western science with the label of Islam or Islamic, or transforming religious norms based the Qur'an and the Hadith to fit empirical data. Both strategies are difficult if the effort is not based on the critic of epistemology.
\end{abstract}

Keywords: Axiology, integration of knowledge, Islam, science

\section{INTRODUCTION}

Axiology is a philosophical perspective that defines what is, (the nature of things). It includes values, guidelines on understanding truth and reality, such as social life, physical objects and symbols. In addition, axiology sets rules upon implementing knowledge into practices. It is a branch of philosophy which seeks the answers on how human being uses their knowledge (Sumantri, 2003). Axiology derives from Greek, axion (values) and logos (theory), which is a theory of value. In other words, it asks questions as why knowledge is needed and how it is used, what are the relationship between its implementation and moral values, how to determine the object of investigations and moral values, and what are the relationship between scientific methods with moral values and professionalism.

According to Bramel, axiology is divided into three categories: moral conduct generating ethics, aesthetical expression, which generate beauty, and, socio-political life resulting in socio politics. Meanwhile in Ensyclopedia of Philosophy, axiologi is seen in three different values as value as an abstract noun, value as a concret noun, and value in a verb, such as judging, giving value, and being valued.

The definition suggests that the main focus of axiology is value and and giving values, and thus one's values determine people's ways of decision making on certain objects. Meanwhile, axiology is the study of value as sugested by Prasetya, and value itself is an invaluable entity needed by all people. Value is seen as: physical value (The value of life, the value of blessing and the value of doing), and spritual value (intellectual, aesthetics, ethic and religious values). Out of the above many values, the value of life is mankind's basic needs, and the value of religion is ones' fundamental needs.

\section{a. Al-Quran and Science}

Al-Quran was revealed to mankind to set the distinction between the righteous and the falsehood; it is a supreme guidance for mankind, as suggested in the following verse of the Qur'an:

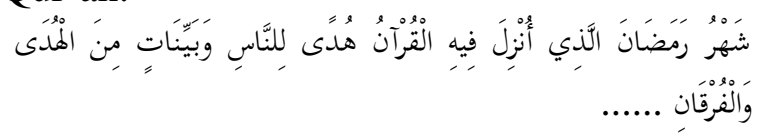


Meaning: The month of Ramadhan, in which the Qur'an was revealed as the guidance for mankind, and the explanation of good and evil (AlBaqarah 185).

Al-Qur'an requires mankind to fulfill their role as human being including seeking knowledge. Al-Qur'an thus perceives those who have knowledge among those of high rank. Allah says:

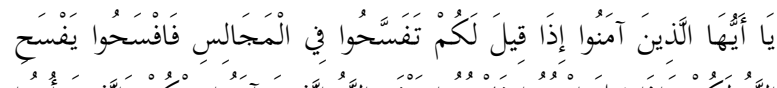

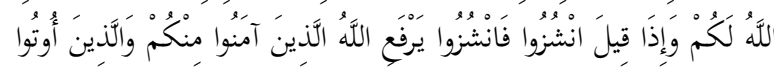

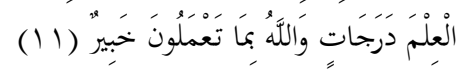

Meaning: Oh who believe, if you are to give space in a gathering, please do so, may Allah will bestow upon you the way out, and if it is said 'stand', please stand, indeed Allah will raise several degrees the position of those who believe among you and those who have knowledge, and Allah all informed of what you do. (QS: alMujadilah: 11)

There are many verses in the Qur'an that encourage someone to seek for knowledge. In fact, the first revelation brings this message. Allah says:

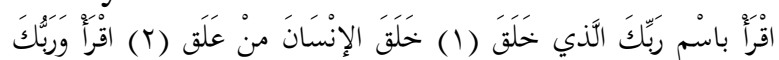

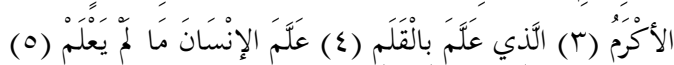

Meaning: Read (by saying) the name of your lord who has created you, $\mathrm{He}$ created human being from a cloth of blood. Read, and your lord is the most merciful, who teaches (mankind) with the pen those which (mankind) do not understand. (QS. Al-'Alaq: 1-5).

In addition, the Al-Quran values one's five sense by which mankind seek knowledge. Allah says:

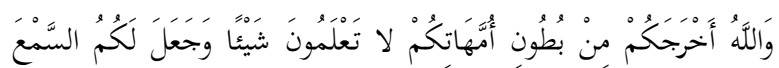

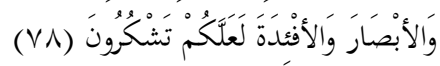

Meaning: Allah bring you out from your mother's womb not knowing a thing, and $\mathrm{He}$ gives you hearing, sight, and heart so that you are thankful (QS.Al-Nahl: 78)

According to Syeikh Mahmud Abdul Wahab Fayid this verse mentions first and foremost of sight and hearing over heart. This is because the former are the source of knowledge and rationality (Fayid, 1989).

Imam al-Ghazali as cited by Quraish Shihab states that all known and unknown sciences derive from al-Qur'an al-Karim. While Imam Al-Syathibi (w. 1388 M), contradicts this opinion (Sihab, 1992). He emphasizes that the relationship between science and the Qur'an neither can be judged by the number of science discussed in it nor by the number of theoretical framework exists in the Qur'an. In discussing this relationship, scholars should do so in such a way that does not reduce the value of the noble Qur'an. This relationship cannot be seen by examining if Mathematics, Biology, Computer Science and other branches of science exist in the Qur'an. This relationship should be seen if the verses of the Qur'an inhibit the advancement of knowledge and if the Qur'an contradicts technological and scientific invention.

Kuntowijoyo states that Al-Qur'an could be taken as the main source of thinking, and this way of thought is referred to Qur'anic paradigm and Qur'anic outlooks, or Islamic paradigm. The development of science based on Qur'anic outlooks has indeed enriched scholarly world. This effort triggers the development of alternative knowledge. This shows that normative premise in the Qur'an could be transformed into empirical theory and rationality for the sake of human being's pragmatic needs (Kuntowijoyo, 2005).

\section{The Reconstruction of Islamic Science}

In the scientific world, there has been a widely known division of knowledge; Islamic and general knowledge, which is then seen as dichotomy of knowledge. This phenomenon has existed from the middle century of Islamic 
history to the recent times. In the Indonesian context, In the Indonesian context, dichotomy of knowledge has been legalized. This is so because Indonesia has two types of educational institutions, one under the supervision of Ministry of Religious Affairs, while the other under the management of Ministry of National Education and Culture.

The idea of knowledge dichotomy is not relevant with the view of the integrated of knowledge and the beginning phase of Islamic history. The perception on dichotomy of knowledge has made Muslim schools left behind, since they are no longer able to solve problem through multi dimensional approach. It is for this reason that the perception of knowledge dichotomy has been persistently rejected by many Muslim scholars. The effort on the Islamization of knowledge emerges as the response for this concern (Putuhena, 2005).

Muhammad Abid al-Jabiry cited in Amin Abdullah states that the backwardness of Islamic civilization dues to the disintegration between natural sciences (al-ulum alkauniyyah) with 'Islamic Science', which based on the sacred text, the Qur'an. In fact, Islamic civilization has produced widely popular scholars, such as Al-Biruni (w. 1041) Muslim encyclopedic, Ibn Sina, the philosophers and medical expert, Ibn Haitsam (w.1039) a Physician, and many others. Unfortunately, most Islamic higher Institutions in the recent times do not recognize these names and miss to learn their theories for the sake of developing 'Islamic Science' (Abdullah, 2007).

Other scholars such as Abu Abbas alFadhl Hatim an-Nizari (w-922) an astronomist, Umar Ibn Ibrahim al-Khayyami (w.1123) popularly known as Umar Khayyam wrote the book of Aljabar, and Muhammad al-Syarif alIdrisi (1100-1166) a geography. These scholars were popular during Islamic classic period, VIIXIII century), known as the golden age of Islam. During these periods, Islamic civilization was in its peak for several reasons:

1. Muslims believe that seeking for knowledge is an obligatory as Muslims, and thus Islamic teaching was a triggering factor.

2. The unitary in language, which enable the discussion on science.

3. The government's policy that support the development of science.

4. The establishment of laboratories, libraries and also education institution.

5. Scholars' passion to do research and learn new knowledge.

6. Openness to external world.

7. The control of regions, in which Greek philosophy has been established.

In the classic period of Islamic civilization, dichotomy of knowledge was not recognized although science based on the sacred book, the Qur'an and those based on research and natural phenomenon have been developed. In these periods, knowledge was still under one framework where there is no separation between Islamic Science and General Science (Putuhena, 2005).

Since XIII century, the popularity of Islamic science reduce significantly, Muslim scholars have been lack of ability to produce new knowledge. While in the west, development of knowledge improve significantly that take them to the renaissance and reformation.

Science which is developed based on Qur'an and the Hadith framework has been regarded as Islamic knowledge, while that developed based natural and experimental phenomenon is seen as non Islamic knowledge. This perception triggers the emergence of dichotomy of knowledge. If this perception persistent, there will be negative impact in human life. For example, nuclear weapon will be used as weapon of mass destruction, instead of being used for human being prosperity.

For this reason, there should be efforts made to deconstruct this perception. Science is integrated, there is no such thing as Islamic 
science and general science. This is so because science is neutral; it is value free. If this perception can be deconstructed, the idea of dichotomy of science will not prevail (Putuhena, 2005).

\section{The Integration of Islamic Science and General Science.}

Since the setback of Islamic civilization in XIII-XIX century, the western world took advantage to develop itself, and this development is known as renaissance. At the time, general science developed significantly, while Islamic science experience major setbacks and this trigger the emergence of dichotomy of science.

In addition to the development of general science, scholars make an attempt to secularize the science although it was opposed by the church. Galileo (L. $1564 \mathrm{M}$ ), the father of secularization of science was sentenced to death in $1633 \mathrm{M}$, for his contradicting opinion with the church perception. Galileo confirm Copernicus' ideas that sun is the center of the universe based on empirical observation and experiment, while the church emphasizes that earth is the center of the universe based on the preaching of the Bible (Sriasumantri, 1986).

Punishing scholars for their dissenting views by the church triggers the separation between science and religious doctrines. This fact reduces the credibility of the church, and thus the scientific views develop into secular science (Mahmud, 1996). In the view of ontology, the secularization of science rejects all religious and mystical views.

In the view of methodology, the secularization of science uses rationalism and empiricism epistemology. Rationalism believes that ratio is an objective tool to view the realities constantly, while empirism views science as empirical. In the view of axiology, science is seen as neutral and value-free; the value of science is given by its users. Giving value to science reduces the objectivity of the science as suggested by secularism (Mahmud, 1996).

This condition motivates Muslim scholars to reintegrate science and religion. The first attempt made is my giving ideas on the Islamization of science. The attempt to Islamize the science in the Islamic world is dilemmatic, whether to wrap western science with the label of Islam or Islamic, or transforming religious norms based the Qur' an and the Hadith to fit empirical data. Both strategies are difficult if the effort is not based on the critic of epistemology. Among Muslim scholars who start the debate on Islamization of science are Ismail Raji AlFaruqi, Syed Muhammad Naquib Al-Attas, Fazlur Rahman, dan Ziauddin Sardar. However, the discussion on the Islamization of science is still inconclusive although this discussion has been going on since the $15^{\text {th }}$ century.

The first Muslim scholar who raised the issue of Islamization of science is Isma'il Raji Al-Faruqi, a Palestinian who migrated to the USA. He made an effort to take science back to its fundamental source, with is the tauhid-the oneness of GOD. This is to show a close tie between faith and science.

The other effort taken to solve this problem is to combine Islam and science. This suggestion is raised by Kuntowijoyo who suggests the need to formulate theoretical framework based on the Qur'an, and thus make the Qur' an as the paradigm. Islam is referred to objective knowledge, which makes Islamic teaching beneficial for mankind. The inquiry that needs answering if the integrations of science/the Islamization of science can be done without referring to theological normative.

Moh. Natsir Mahmud propose several propositions that make the Islamization of science feasible:

1. In Islamic point of view, the universe as the object of science is not value free. It has value and has noble purposes. If science is used for good purposes, it will generate goodness to society. 
2. Science is the product of human being's thought based on the observation of the phenomenon in the universe. For that reason, science is developed differently through different methodology.

3. In Islamic point of view, seeking knowledge is not merely a debate on rationality and experiment, but it involves the spiritual being. Rationality and experiment describe the fact, while the spirituality defines the fact, which generate meaningful conclusion.

4. Islam perceives that reality is not only physical, it is non-physical and in fact, it is metaphysical. This perception is received by the ontology of rationalism, which believes that empirical facts are multiple: sensual, rational, ethic and transcendental fact (Mahmud, 1996).

Azyumardi Azra states that Muslim scholars differ in their perception on religious science and general science:

First: Restorationist, the useful and needed science is the practices of religious teaching. Ibrahim Musa (w. 1398 M) from Andalusia is one of the scholars that promote this idea. Ibnu Taymiah, for example says that the only science is the one comes from the prophet. Likewise, Abu Al-A'la Maududi, the leader of jamaat al-Islam Pakistan, emphasizes that western science, such as Geography, Physics, Chemistry, Biology, Zoology, Geology, and Economics are misled because they are not derived from Allah and Prophet Muhammad.

Second: Reconstructionist, who reinterpret of religion to develop the relationship of modern civilization and Islam. They stress that Islam in the time of Prophet Muhammad and companions was very reformative, progressive, and rational. Sayyid Ahmad Khan (w. 1898 M) states that God's revelation and scientific evidence are both true, and thus Jamal al-Din al-Afgani states that Islam stresses on scientific activities.

Third: Reintegration, it is the reconstruction of science of al-ayah al-
Qur'aniyah and of al-ayah al-kawniyah, which means that the two branches of science is transcendental (Azra, 2005).

Kuntowijoyo (2005) states that the essence of integration is the attempt to unite not to combine God's revelation and mankind's invention and theories per se, not to denigrate God's value (secularism) and also human being or other worldly asceticisme. The basic premise of integration is to establish the Qur'an and the Prophetic Tradition as grand theory of science so that ayat-ayat qauliyah and qauniyah can be utilized (Suproyogo in Bagir, 2005).

The purpose of this integration is to integrate the two sciences by maintaining the uniqueness of the two.

Although many scholars respond positively to the idea of integration, some scholars emphasize that the integration process should be done in such a way, so that the following practices will be prevented from happening:

1. The integration that only attempt to fit the Qur'anic verses with scientific discoveries. The integration that is encouraged is the one that produces new knowledge, in which the knowledge will not be developed unless the two branches of science are integrated. Integration is needed if the separation of the two branches of science generates negative impacts (Bagir, 2005).

2. In terms of the division of science, qauniyah (universe) and qauliyah (theology). Kuntowijoyo states that science is not merely qauniyah, related to regulations of the universe and qauliyah, which is related to God's regulation but also nafsiyah, which is related to meaning, value and awareness. The nafsiyah is also known as humaniora (Kuntowijoyo, 2005).

Amin Abdullah suggests that it is difficult to integrate Islamic and general science, since the two are in conflict with each other. Therefore, there is a need to connect the two branches of science wisely, Amin Abdullah 
states that: "One needs to understand complex phenomenon experienced by mankind, in which Sociology and Natural Science do not stand alone, and thus they need to support each other (Abdullah, 2006).

Integration-interconnected is a type of integration, which aims to support others, without the attention to mix the two branches of science. Three ways of interconnectedness available: parallel, linear dan circular.

- In parallel integration, the two branches of science are developed independently.

- In the Linear approach, one out of the two sides becomes prominent, and that is accused to have understanding on the possibility of subjective.

- The circular approaches both branches of knowledge reflect on their own strengths and weaknesses and learn from each other (Abdullah, 2006).

This kind of integration is an attempt to integrate Islamic science and general science. The basic premise of this type of integration is to promote the objectivity of science so that all people regardless of their religion see it as natural, not as religious deity (Kuntowijoyo, 2006).

One of the obvious examples of the process of objectivity of Islamic science is the establishment of Sharia economics, in which its principles are based on religious teaching. Islam provides principles in how people engage in business, such as benefit sharing (alMudharabah) and collaboration (alMusyarakah). This example shows how Islamic principles benefit not only Muslims but also non-Muslims. In the future, this kind of integration can be applied to Psychology, Sosiology, Anthropology, Health, Technology, Economics, Politics, International Relation, Law and Justice (Abdullah, 2006).

The differences between integrationinterconnected and Islamization of Science is in regard with the relationship between Islamic Science and General Science. This integration model respects general science, since it has its own epistemology, ontology dan axiology, which has developed similarity in approach and procedure, which includes principles in Islamic science so that both branches of knowledge can work and support each other.

This suggests that upon integration, one needs to pay attention on ontological, epistemological dan axiological perspectives.

- From the ontological perspective, science derives as the result of systematic and comprehensive examination about verses of the Qur'an. Because of our difficulties in understand this verses. Because of this difficulty mankind will not be able to gain the whole truth because the absolute truth belongs to Allah.

- In the Epistemological perspective, science is obtained through technology and through the instruments, it also uses sight, hearing, and heart/wisdom.

- In the axiological perspective, science should be directed to give advantage for mankind. Science in fact should be led to destruct the life of mankind.

\section{CONCLUSION}

1. Al-Qur'an was revealed to mankind as the guidance, which separate good and evil. It was also revealed to encourage mankind to seek for knowledge and develop science.

2. Since the decline of Church credibility, scholars develop what so called secular science.

3. Muslim scholars have to deconstruct the perception of dichotomy of science through Islamization of science or integration of the two. This is need to be done to prevent bad impact.

4. Three typologies of Muslim scholars' response in regard with the integration of science: Restorasionist, Reconstructionist, dan Reintegration.

5. The integration of Islamic and general science was done through integrationinterconnected, referring to ontological, epistemological dan axiological perspectives. 


\section{REFERENCES}

Abdullah, A. (2006). Islamic Studies Di Perguruan Tinggi: Pendekatan Integratif-Interkonektif, Yogyakarta: Penerbit Pustaka Pelajar.

Abdullah, A., dkk. (2007). Islamic Stadies dalam Paradigma IntegrasiInterkoneksi, Yogyakarta: Penerbit Suka Press.

Azra, A. (2005). Reintegrasi Ilmu-ilmu dalam Islam Zainal Abidin Bagir (ed) Integrasi Ilmu dan Agama, Interprestasi dan Aksi, Bandung: Mizan.

Bagir, Z.A. (2005). Integrasi Ilmu dan Agama, Interprestasi dan Aksi, Bandung: Mizan.

Kuntowijoyo. (2005). Islam Sebagai Ilmu, Jakarta: Teraju.
Mahmud, M.N. (1996). Landasan Paradigmalik Islamisasi Ilmu Pengetahuan, in Nurman Said, Wahyuddin Halim Muhammad Sabri, (ed), Op.cit; h. 129.

Shihab, M. Q. (1992). Membumikan Al-Qur'an, Bandung: Penerbit Mizan.

Putuhena, M.S. (2005). Ke Arah Rekonstruksi Sains Islam, Nurman Said, Wahyuddin Hakim, Muhammad Sabri, Sinergi Agama dan Sains, (ed) Makassar: Alauddin Press, Cet I. 2005.

Fayid, S.M.A.W. (1989). Al-Tarbiyah Fie Kitab Allah, diterjemahkan Judi Al.Falasany, "Pendidikan Dalam Al-Qur'an" Semarang: Penerbit CV.Wicaksana.

Sumantri, J.S. (1986). Ilmu dalam Perspektif Moral, Sosial dan Politik, Jakarta: Gramedia, 1986.

(2003). Filsafat Ilmu, Jakarta: Pustaka Sinar Harapan. 